UDK 334.723

DOI: 10.54649/2077-9860-2020-4-33-39

\author{
Shaimerden Chikanayev ${ }^{{ }^{*}}$ \\ ${ }^{1}$ LL.M., GRATA International Law Firm, \\ Republic of Kazakhstan, Almaty \\ E-mail: schikanayev@gratanet.com
}

\title{
PUBLIC-PRIVATE PARTNERSHIPS IN KAZAKHSTAN: EVOLUTION OF THE GOVERNMENT POLICY AND REALITY OF PPP DEPLOYMENT.
}

\author{
PART I ${ }^{* * *}$
}

\section{Annotation}

This article examines PPP development in Kazakhstan from 1991 to the time of writing. Article reviews evolution of the PPP legislation and approaches used to develop a PPP-enabling environment in order to draw lessons for the country's future policy. This article describes evolution of the PPP concept in the country and provides analysis of gaps and deficiencies in the current PPP policy and legislation.

The PPP definition and the scope of PPP activity has evolved significantly in the nation's legislation and legal literature since 1991. Author distinguish the following five stages of the PPP development in Kazakhstan: Stage One-PPP legal framework for foreign investors only (1991-1993); Stage Two-Lack of PPP-specific legal framework and "pilot" projects (1994-2005); Stage Three-The formation of legal and institutional frameworks (2006-2015); Stage Four-Active PPP deployment: the focus being on quantity (2016-2018); Stage Five-Adjustments to the PPP framework: stricter requirements (2019present).

In this article, the author examines the first two stages from 1991 to 2005, paying attention to the actions of the government, Policy Goals at the Stage One and Stage Two, assessing the implications for further policy development of public-private partnerships in the state. The author concludes that at the end of the first stage, unlike the first law on concessions, all PPP-related laws thereafter have been applicable to both domestic and foreign investors, as the government realised the importance of treating all investors equally. Stage Two also showed that Kazakhstan needs more effective PPP policy instruments for the implementation of projects in the utilities sector.

Key words: public-private partnership, politics, government, investor, investment, economy, infrastructure, concession, contracts, agreements.

\author{
Ш.А. Чиканаев ${ }^{1}$ \\ ${ }^{1}$ 3.F.M., GRATA халықаралық заң фирмасы, \\ Қазақстан Республикасы, Алматы қ. \\ E-mail: schikanayev@gratanet.com
}

\footnotetext{
* S. Chikanayev (B ).GRATA International Law Firm, Almaty, Kazakhstan. Shaimerden Chikanayev is an advocate of the Almaty City Bar and a partner of GRATA International Law Firm, Almaty, Kazakhstan. He has over 13 years of experience in Kazakhstan's legal services market, and significant experience in matters relating to countries of Central Asia. His practice focuses on a wide range of finance and mergers and acquisitions transactions. Shaimerden has extensive knowledge of various industries, and in particular energy, utilities and social infrastructure, financial services, and transportation.

** This article is based on materials published in: Kazakhstan's Developmental Journey. Entrenched Paradigms, Achievements, and the Challenge of Global Competitiveness/ Edited by Anastasia Koulouri\&Nikolai Mouraviev/ S. Chikanayev Ch. 6. Public-Private Partnerships in Kazakhstan: Evolution of the Government Policy and Reality of PPP Deployment /ISBN 978-98115-6898-5 ISBN 978-981-15-6899-2 (eBook) https://doi.org/10.1007/978-981-15-6899-2 @ The Editor(s) (if applicable) and The Author(s), under exclusive license to Springer. Nature Singapore Pte Ltd. 2021. P. 153-180.

*** $\quad$ For the convenience of readers, the article was divided into two parts by the decision of the editorial board. Part II will be published in the next issue of the journal.
} 


\title{
ҚАЗАҚСТАНДАҒЫ МЕМЛЕКЕТТІК-ЖЕКЕМЕНШІК СЕРІКТЕСТІК: МЕМЛЕКЕТТІК САЯСАТЫНЫҢ ЭВОЛЮЦИЯСЫ ЖӘНЕ МЖӘ ОРНАТУДЫҢ ШЫНДЫҒЫ.

\author{
І БөлІм
}

\section{Аңдатпа}

Бұл мақалада Қазақстандағы МжӘ-нің 1991 жылдан бастап мақала жазылған сәтке дейінгі дамуы зерттелінген. Онда МЖӘ туралы заңнамасының эволюциясы және елдің болашақ саясатына сабақ алу үшін МЖӘ үшін қолайлы жағдай жасау тәсілдері қарастырылды. Бұл мақалада елдегі МжӘ тұжырымдамасының эволюциясы сипатталады және МжӘ аясындағы қолданыстағы саясатындағы және заңнамасындағы олқылықтар мен кемшіліктер талданады.

Мжә анықтамасы және МжӘ қолдану аясы 1991 жылдан бастап ұлттық заңнамада және заң әдебиеттерінде айтарлықтай өзгеріске ұшырады. Автор Қазақстандағы Мжә дамуының келесі бес кезеңін бөліп көрсетеді: Бірінші кезең - бұл тек шетелдік инвесторларға арналған МжӘ-нің құқықтық негіздері (1991-1993 жж.); Екінші кезең - Мжә және «пилоттық» жобалар үшін нормативтік-құқықтық базаның жоқтығы (1994-2005); Үшінші кезең - құқықтық және институционалдық базаны қалыптастыру (2006-2015 жж.); 4 кезең - Белсенді МжӘ қолдану: санға негізінен назар аударылады (2016-2018); Бесінші кезең - Мжә құрылымын түзету: неғұрлым қатаң талаптар қойылады (2019 жылдан бастап қазіргі уақытқа дейін).

Бұл мақалада автор үкіметтің іс-әрекеттеріне, қарастырылып отырған жекелеген кезеңдердегі саяси мақсаттарға назар аудара отырып, мемлекеттегі мемлекеттік-жекеменшік серіктестікті дамытудағы саясаттың салдарын бағалай отырып, 1991-2005 жылдар аралығындағы алғашқы екі кезеңді қарастырады. Автор бірінші кезеңнің соңында, бірінші концессия туралы заңнан айырмашылығы, МЖӘ қатысты кейінгі барлық заңдар ішкі және шетелдік инвесторларға қатысты болды деген қорытындыға келеді, өйткені үкімет барлық инвесторларға бірдей қараудың маңыздылығын түсінді. Екінші кезең коммуналдық сектордағы жобаларды іске асыру үшін МжӘ аясындағы саясатының анағұрлым тиімді құралдарына Қазақстан мұқтаж екенін көрсетті.

Түйінді сөздер: мемлекеттік-жекеменшік серіктестік, саясат, үкімет, инвестор, инвестиция, экономика, инфрақұрылым, концессия, келісімшарттар, келісімдер.

\author{
Ш.А.Чиканаев ${ }^{1}$ \\ ${ }^{1}$ M.ю.н., Международная юридическая фирма GRATA, \\ Республика Казахстан, г. Алматы \\ E-mail: schikanayev@gratanet.com
}

\section{ГОСУДАРСТВЕННО-ЧАСТНОЕ ПАРТНЕРСТВО В КАЗАХСТАНЕ: ЭВОЛЮЦИЯ ГОСУДАРСТВЕННОЙ ПОЛИТИКИ И РЕАЛЬНОСТЬ РАЗВЕРТЫВАНИЯ ГЧП. ЧАСТЬ I}

\begin{abstract}
Аннотация
В данной статье исследуется развитие ГЧП в Казахстане с 1991 года до момента написания статьи. Рассматривается эволюция законодательства о ГЧП и подходы, используемые для создания благоприятной среды для ГЧП в целях извлечения уроки для будущей политики страны. В данной статье описывается эволюция концепции ГЧП в стране и проводится анализ пробелов и недостатков в действующей политике и законодательстве в области ГЧП.

Определение ГЧП и сфера деятельности ГЧП претерпели значительные изменения в национальном законодательстве и юридической литературе с 1991 года. Автор выделяет следующие пять этапов развития ГЧП в Казахстане: Первый этап- правовая база ГЧП только для иностранных инвесторов (1991-1993 гг.); Второй этап - отсутствие нормативно-правовой базы по ГЧП и «пилотных» проектов (1994-2005 гг.); Третий этап - формирование правовой и институциональной базы (2006-2015 гг.); Четвертый этап - развертывание активного ГЧП: основное внимание уделяется количеству (2016-2018 гг.); Пятый этап - корректировка структуры ГЧП: более строгие требования (с 2019 г. по настоящее время).

В данной статье автор рассматривает первые два этапа с 1991 по 2005 годы, уделяя внимание
\end{abstract}


действиям правительства, политическим целям на отдельных рассматриваемых этапах, давая оценку последствия для проведения дальнейшей политики в сфере развития государственночастного партнерства в государстве. Автором делается вывод, что в конце первого этапа в отличие от первого закона о концессиях, все последующие законы о Гчп были применимы как к отечественным, так и к иностранным инвесторам, поскольку правительство осознало важность равного отношения ко всем инвесторам. Второй же этап также показал, что Казахстану необходимы более эффективные инструменты политики ГЧП для реализации проектов в коммунальном секторе.

Ключевые слова: государственно-частное партнерство, политика, правительство, инвестор, инвестиции, экономика, инфраструктура, концессия, контракты, соглашения.

\section{Introduction}

A number of policy documents indicate that over many years Kazakhstan has been showing political will to develop public-private partnerships $^{1}$ (PPPs). Not only did the government set a well-established legal (i.e. hard law) and institutional framework for PPPs, but also officially confirmed its commitment to develop the PPPs in its soft law, including in the Kazakhstan-2050 Strategy [1] and the 2025 Strategic Development Plan. By 2019, however, it became increasingly evident to all major stakeholders that PPP development in Kazakhstan was going in the wrong direction, as the PPP policy and governance proved to be

inefficient and have often been used to conceal public borrowing. The problems of the PPP mechanism not working properly became so acute that in 2019 the President of Kazakhstan, Mr KassymJomart Tokayev, acknowledged that the whole concept of PPP in Kazakhstan had been discredited [2]

However, in 2020, Kazakhstan is facing major economic and social challenges due to the impact of the COVID-19 pandemic and drop in the price of oil to a 20-year low, which has resulted in decreased economic activity, devaluation of local currency (tenge), reduced foreign direct investment, and shrinking state budget. This makes the need to attract investment in deteriorating public infrastructure even more acute, and the government is now under even greater pressure to find answers to hard questions about maintaining the volume and quality of public services. Therefore, Kazakhstan's government needs to take action in the near future to recalibrate the PPP policy and the way it is implemented.

$1^{1}$ This chapter does not discuss the definitions, features, and models of public-private partnerships. For the general understanding of PPPs, please see Mouraviev, N., \& Kakabadse, N. (2016). Conceptualising public-private partnerships: A critical appraisal of approaches to meanings and forms. Society and Business Review, 11(2), 155-173.

(c) The Author(s) 2021. A. Koulouri and N. Mouraviev (eds.), Kazakhstan's Developmental Journey, https://doi. org/10.1007/978-981-15-6899-2 6
This article examines PPP development in Kazakhstan from 1991 to the time of writing and reviews evolution of the PPP legislation and approaches used to develop a PPP-enabling environment in order to draw lessons for the country's future policy. This article describes evolution of the PPP concept in the country and provides analysis of gaps and deficiencies in the current PPP policy and legislation.

Since 1991 when Kazakhstan declared its independence, it has had to rely on the deteriorating infrastructure it inherited from the Soviet era. As a result, nearly every element of public infrastructure, such as roads, airports, water networks, and hospitals, required upgrading or expansion. Faced with gloomy growth projections and shrinking budgets after the collapse of the Soviet Union, Kazakhstan's government quickly recognised that it could use an effective method for attracting private investors and financing its growing infrastructure needs: PPPs. As the concept was novel for the country, the PPP definition and the scope of PPP activity has evolved significantly in the nation's legislation and legal literature since 1991.

It is, therefore, useful to distinguish the following five stages of the PPP development in Kazakhstan:

- Stage One-PPP legal framework for foreign investors only (1991-1993).

- Stage Two-Lack of PPP-specific legal framework and "pilot" projects (1994-2005).

- Stage Three-The formation of legal and institutional frameworks (2006-2015).

- Stage Four-Active PPP deployment: the focus being on quantity (2016-2018).

- Stage Five-Adjustments to the PPP framework: stricter requirements (2019-present).

Each stage will be discussed in detail, followed by the conclusion.

\section{Stage One- PPP Legal Frame work for Foreign Investors Only (1991- 1993)}




\section{What Was Done}

Just seven days after it declared its independence, Kazakhstan adopted the law on concessions, which was the first PPP-related law in the country. The new legal framework has been proofed and applied in at least four infrastructure projects financed by the Development Bank of Kazakhstan and three concession projects supported by the national government.

\section{Policy Goals at This Stage}

The principal peculiarity of the first law on concessions was that at this initial stage of the PPP development a concession was viewed as an exclusive right or authorisation (i.e. de facto a licence) issued by the government to a concessionaire to engage in certain business activities. In other words, a concession agreement was some kind of an "administrative contract" [3] that should not even be treated as a civil law agreement between equal parties because de facto it was a unilateral government authorisation (i.e. a licence) based on the provisions of public law [4] .

Although the law on concessions was not industry-specific, it has been designed mainly for implementation of projects related to utilisation of natural resources. As at that time oil and gas were viewed as the only possible drivers of the national economy, it was well justified that the law was tailor-made for the oil and gas projects.

Importantly, the law on concessions could be used only by foreign investors as the law stipulated that a concession could be granted only to foreign legal entities and/or citizens. When the Soviet Union disintegrated, there was no market economy in Kazakhstan and no local businesspeople who could act as concessionaires. It is, therefore, natural that at the dawn of Kazakhstan's independence, attracting foreign direct investment was the main PPP policy goal aiming at bringing in money and technology for exploration and extraction of the country's oil and gas reserves.

\footnotetext{
Assessment

The scope of the PPP concept during Stage One was limited to the concession form. It was understood narrowly as an exclusive right to be awarded to an investor (in some countries, a concession is understood in the same way as exclusive right, although in others it is viewed as one of many types of a PPP agreement; see, for example, Tuktarov and Dubinchina [5]). Stage One represents a time when the government was not yet ready for any partnership with business on equal terms and, therefore, the whole PPP model (i.e. a licensed-
}

type concession agreement based on public law provisions) was designed to enable the state to dictate its terms of partnership to the business. It is no surprise, therefore, that just a handful of projects had been implemented under this novel legal framework. The first law on concessions was already deemed invalid by April 1993.

Implications for Further Policy Development

Rapid transition to a market economy in the 1990s exposed deficiencies of the licensed-type concession agreement under the law on concessions, which proved to be a hindrance for attracting private investment. The government learned its lesson and all new types of PPP-related agreements it introduced thereafter have been based on private law and not public law provisions. Instead of the power-subordinate relationship that existed under the first law, all PPP-related types of agreements introduced in Kazakhstan after 1993 have been based on the "equality of parties" principle.

Another lesson Kazakhstan learned from this stage is that PPP-related laws should be tailormade for developing public infrastructure (economic infrastructure and social infrastructuresee Yescombe and Farquharson [6]) and not for the subsoil utilisation projects. This materialised in 2006 when a new Concession Law specifically excluded subsoil use operations from its application (Law of the Republic of Kazakhstan [7]). From 2006, the legal term "a concession agreement" could not be applied to any type of the subsoil use contracts (Bassin et al. [8]), whereas the Law on Public-private partnership (the PPP Law) (Law of the Republic of Kazakhstan [9]) adopted in 2015 includes the provision that the term may be applicable to projects involving subsoil use but only in conjunction with the provisions of the Subsoil Use Code.

Finally, unlike the first law on concessions, all PPP-related laws thereafter have been applicable to both domestic and foreign investors, as the government realised the importance of treating all investors equally.

\section{Stage Two - Lack of PPP - Specific Legal Frame work and "Pilot" Projects (1994-2005)}

\section{What Was Done}

From 1993, when the first law on concessions stopped working, to 2006,

when a new law on concessions came into effect (i.e. for about 13 years), there was no PPPspecific legislation in Kazakhstan. Despite the ab- 
sence of any specific laws on PPPs or concessions, a number of agreements have been executed during this time between public law entities (i.e. the Republic of Kazakhstan, its regions or cities) and investors, based on PPP principles and relying solely on the general principle of freedom of contract in Kazakhstan's civil law.

Privatisation of the country's electrical power and heating infrastructure using the PPP mechanism, in the second half of the 1990s in particular, triggered interest amongst foreign investors. In 1997, the Belgian company Tractebel obtained the "concession" for the electricity, heating, and gas supply in the city of Almaty (the nation's then capital), as well as the licence for the construction and operation of gas pipelines. The American company AES also received concessions for the provision of electricity and heating in the same year and invested in some of the country's largest power plants, including the 4000 MW Ekibastuz-1 coal-fired power station. However, the foreign investors quickly faced high-profile disputes with the government. Disagreements regarding tariffs and a corruption scandal resulted in the early termination by Tractebel of its investment in the beginning of the 2000s. Similarly, amid regulatory disputes with the government, AES sued Kazakhstan before investment arbitration and divested its largest energy assets in the country in order to gradually close down its Kazakhstan-based business (Boute [10]).

Nonetheless, the other two infrastructure projects were launched as concession agreements in 2005, despite the absence of a specific legal framework. These projects are usually viewed by the government as pilot PPP projects (although they were not the first ones as there were others, as discussed above):

1. Construction and operation of the inter-regional power transmission line "North Kazakhstan Aktobe Region" in the Aktobe region (a concession for 25 years with a concessionaire Batys Transit).

2. Construction and operation of the railway line "Shar Station - Ust- Kamenogorsk" in East Kazakhstan region (a concession for 23 years with a concessionaire Doszhan Temir Zholy) (for details of this project, see Eurasian Economic Commission [11]).

Both concessions performed below expectations and could hardly be viewed as successful PPP projects. In part, this was caused by poor structuring of these projects. In addition, there was apparent lack of proper balance of risk sharing between an investor and the state. For exam- ple, the railway has seen less freight than expected, which had a serious negative impact on the project's revenue. In the power transmission project, although several enterprises were expected to use the power line, they were not working or operating below full capacity. Both concession projects managed to raise debt financing on the domestic stock exchange by issuing infrastructure bonds secured by the state sureties. These state sureties issued their guarantees under Kazakhstan's law. However, their guarantees proved to be unreliable means of security in practice. Doszhan Temir Zholy (the operator of the "Shar Station Ust-Kamenogorsk" railway line project) declared default on its infrastructure bonds in 2008, and many of Kazakhstan's pension funds that acquired these bonds failed to enforce their claims against the Republic of Kazakhstan as a surety. After some time, however, in the light of looming loan defaults and risk of bankruptcies of the companies involved, the government stepped in and rescued both pilot PPP projects by purchasing part of the shares from private investors.

\section{Policy Goals at This Stage}

Foreign participation in the privatisation of electrical power and heating generation and supply was an important component of the government's successful policy to address a severe debt crisis that hit Kazakhstan's energy sector at the end of the 1990s (Boute [10]). The government expected that attracting foreign investors by way of PPPs and privatisation would (i) facilitate the restructuring of the debts accumulated by the state-owned operators of utilities, (ii) bring in much-needed capital and technology for the modernisation of the energy sector and (iii) reduce the budget expense on the power and heating generation.

In addition to upgrading public infrastructure, the government also hoped to use PPPs for developing the domestic capital market by introducing a new financial instrument-infrastructure bonds - that were expected to become a lucrative and, importantly, secure asset for investment by the nation's pension funds, insurance companies, and other large firms.

\section{Assessment}

Stage Two captures government-business relations in Kazakhstan at a time when the government tried to use PPPs and privatisation in the most flexible and unregulated manner to do much-needed reforms in the energy and utilities 
sectors and swiftly attract foreign and domestic investment. Yet, the government learned the hard way that there are not really any shortcuts to forge a lasting partnership with the private sector.

The second stage, therefore, presents particular interest for legal research because any form of cooperation between the government and business was, de facto, recognised as PPP and all projects implemented as such during this time have been structured and launched in the absence of a PPP-specific legal framework. The absence of specific legislation means that the legality and enforceability of the so-called concession agreements remain questionable. De jure these agreements could not be qualified as concession agreements as provided by the 2006 Concession Law but should be qualified as so-called innominate contracts (contractus innominati). In particular, one of the grey areas is the legal capacity of public law entities (i.e. the Republic of Kazakhstan, its regions, and certain cities) to enter commercial contracts, if such commercial contracts are not specifically provided by Kazakhstan's law (i.e. if they are not socalled nominate contracts from Kazakhstan's civil law perspective) and if Kazakhstan's law does not specifically authorise relevant state bodies to sign such contracts on behalf of the respective public law entity. In the absence of such specific regulation, transparency of the process related to selecting investors, as well as legal the authority of relevant state bodies (i.e. the national government or regional and local executive bodies) who signed concession agreements on behalf of relevant public law entities, also remains an open issue.

The lack of a transparent private partner selection procedure and the absence of a solid legal framework for structuring PPPs during Stage Two of PPP development in Kazakhstan, unsurprisingly, left too much room for the discretion of government officials and opportunities for corrupt practice. During this stage, many PPP tenders were rigged and lacked competition, being largely controlled by favoured insiders with political connections to the government bodies. It is of no surprise, therefore, that most litigations and corruption scandals surrounding PPP projects occurred during this time (e.g. a dispute between CCL Oil Ltd and Kazakhstan's government in relation to concession agreement executed in 1997 with regards to the Pavlodar oil refinery is just one more example, in addition to AES and Tractebel cases discussed in this section).
Implications for Further Policy Development

The principal lesson from Stage Two is that in order to attract investors on a long-term basis, specific PPP legislation should be adopted to make sure that the private partner selection process is transparent and efficient, whereas authorities of the relevant state bodies should be clearly stipulated in legislation.

The government also realised that the exceptionally low tariffs that were used in the utilities and energy sectors did not enable the utilities companies to recover their costs and attract foreign investors and did not allow viable PPP projects to be launched without additional payments from the state budget. Raising the tariffs for utilities is typically considered a politically unpopular action; it is a sensitive issue that could trigger social unrest. Therefore, the government has been, and still is, reluctant to attract foreign investors and initiate any PPP projects in the utilities sector. This calls for a fundamental reform of the tariff-setting methodology used by the natural monopolies in general and in utilities in particular. Private investors always seek clarity about the government's commitment to adopt a tariff-setting policy that would ensure the financial viability of the contract, although a project often has to be accompanied by the transparent subsidies if the government decides that not all consumers can afford to pay costrecovery tariffs.

Stage Two also showed that Kazakhstan needs more effective PPP policy instruments for the implementation of projects in the utilities sector. For example, it might be a PPP model, specifically provided by law, that allows payments to a private company by both the government and final users or allows shadow tolls (i.e. when the government pays the tolls in place of the final user) to guarantee certain revenue to a private party for a prespecified volume of public services (Mouraviev and Kakabadse [12]) .

Finally, because many pension funds burned their fingers on infrastructure bonds during this stage of PPP development, this type of bondsused as a mechanism for raising debt financing for PPPs - has not been used in Kazakhstan ever since. It shows that the government largely lost interest in the domestic capital market as a source of financing for PPPs and instead opted to attract the necessary funding mainly from international institutions. 


\section{References:}

1. Nazarbayev, N. (2012). Strategy Kazakhstan-2050: New political course of the established state. Available via https://strategy2050.kz/en/page/multilanguage/. Accessed 20 April 2020.

2. Tokayev, K.-J. (2019, July 15). Speech of the Head of State at the meeting of the government [in Russian]. Available via http://www.akorda.kz/ru/speeches/internal_political_affairs/in_speeches_and_addresses/vystuplenie-glavy-gosudarstva-k-tokaeva-na-rasshirennom-zasedanii pravitelstva. Accessed 22 April 2020.

3. Popondopulo, V. F., \& Shevelyova, N. A. (Eds.). (2015). Public-privatepartnership in Russia and foreign countries: The legal aspects [in Russian]. Moscow: Infotropik Media.

4. Moroz, S. (2006). Investment law of the Republic of Kazakhstan [in Russian]. Almaty: NII chastnogo prava KazGYuU.

5. Tuktarov, Y., \& Dubinchina, S. V. (Eds.). (2016). A concession agreement: Its legal nature, scope of application, and execution [in Russian]. Moscow: Statut.

6. Yescombe, E. R., \& Farquharson, E. (2018). Public-private partnerships for infrastructure: Principles of policy and finance. Oxford: Butterworth- Heinemann.

7. Law of the Republic of Kazakhstan. (2006). Law on Concessions [in Russian]. Law No 167 of 7 July 2006. Available via http://adilet.zan.kz/eng/docs/ Z060000167. Accessed 26 April 2020.

8. Bassin, Y., Suleimenov, M., Osipov, E., \& Chentsova, O. (2004). Subsoil use contracts: Issues of legal classification and systematisation. Kazakhstan Business Magazine, p. 1. Available via http:// www.investkz.com/en/journals/38/166.html. Accessed 26 April 2020.

9. Law of the Republic of Kazakhstan. (2015). The Law on Public-private partnership [in Russian]. Law No 379-V of 31 October 2015. Available via http://adilet.zan.kz/eng/docs/Z1500000379. Accessed 26 April 2020.

10. Boute, A. (2019). Energy security along the New Silk Road: Energy law and geopolitics in Central Asia. Cambridge: Cambridge University Press.

11. Eurasian Economic Commission. (2018). PPP in countries of the Eurasian Economic Union. Practical guide for investors [in Russian]. Available via http://www.eurasiancommission.org/ru/act/ finpol/dobd/ppp/Documents/Evrazes_Book-2018_A4.pdf. Accessed 26 April 2020.

12. Mouraviev, N., \& Kakabadse, N. K. (2017). Public-private partnerships: Policy and governance challenges facing Kazakhstan and Russia. London: Palgrave Macmillan. 